\title{
Soil Seed Banks Associated with Individual Broom Snake- weed Plants
}

\author{
ABDELGADER OSMAN, REX D. PIEPER, AND KIRK C. MCDANIEL
}

\begin{abstract}
The influence of individual broom snakeweed (Gutierrezia sarothrae [Pursh] Britt. \& Rushby) plants on the distribution of buried viable seed and the distribution of plants in the field was studied in a desert grassland in southern New Mexico. Surface soil samples collected at 3 distances from a central broom snakeweed plant were watered in pots in a greenhouse and numbers of each species emerging were counted. Densities of each species were also determined in the field. Some species (Sporobolus flexuosus [Thurb.] Rybd., S. contractus Hitchc., Descurainia pinnata [Walt.] Britton, and Dithyrea wislizenü Engelm.) emerged in greatest numbers from soil collected in the zones closest and at the greatest distances from the broom snakeweed. Emergence of other species declined in relation to distance from the central snakeweed plant. In the field, grasses generally increased in relation to distance from the central broom snakeweed plant while the pattern for forbs was not consistent.
\end{abstract}

Key Words: Gutierrezia sarothrae, vegetational zonation

Distribution of individual plants can be controlled by many different abiotic and biotic factors. Emergence of individual plants can also be influenced by seed availability, microenvironment, and allelopathy depending on proximity to established plants. Developing an understanding of these complex interactions is a challenge to those working in the area of soil-plant and plant-plant relationships and requires both complete descriptions of the patterns and experimental testing.

Jenny (1961) and Major (1951) approached the problem by considering vegetation and soils as dependent variables controlled by the independent variables of climate, time, organisms, topography, and parent material. Thus, vegetation is a function of plant propagules present at time zero, as mediated by the other state factors. Some plants may impinge directly on others, e.g., by shading, or indirectly by their influence on soil properties or other microclimatic characteristics. Large, scattered plants may influence plants beneath their canopy, but have little influence in interspaces. Thus, a mosaic of plants with their interspaces is present at a micro-scale of pattern.

The reciprocal relationships among plants is especially relevant in the case of broom snakeweed (Gutierrezia sarothrae [Pursh] Britt. \& Rushby), which became widespread in the Southwest during the 1970s (McDaniel et al. 1984, Ueckert 1979). Broom snakeweed populations fluctuate considerably (McDaniel et al. 1984). Originally, ecologists considered grazing as the major factor responsible for snakeweed outbreaks (Campbell and Bomberger 1934, Talbot 1926). Others now consider climatic variation as the main factor responsible for snakeweed population fluctuations (Jameson 1970, Vallentine 1971, McDaniel et al. 1984).

Several studies have been conducted on buried viable seed in the soil although they were conducted for other purposes (Juhren et al. 1956, Major and Pyott 1966 and Mott 1972). In southern New Mexico Dwyer and Aguirre (1978) found considerable difference in species composition of plants emerging in the greenhouse from soil collected from different range condition classes compared to

\footnotetext{
Authors are former graduate student, professor, and associate professor, Department of Animal and Range Sciences, New Mexico State University, Las Cruces 88003-0009. Journal Article 1265 of The New Mexico Agr. Exp. Sta., Las Cruces 88003-0009.

Manuscript received 9 August 1986.
}

those in the field. Nava (1970) found that more species emerged from soil collected beneath mesquite canopies than from soil collected from open spaces.

Established snakeweed plants may influence the ability of snakeweed itself, and of other species, to propagate. The objective of this study was to determine the number of buried viable seed in the soil around individual broom snakeweed plants, and to compare this potential with actual numbers found around broom plants in the field.

\section{Description of Area}

Portions of the study were conducted on the New Mexico State University College Ranch, $32 \mathrm{~km}$ north of Las Cruces in Dona Ana County. The rest of the study was conducted in a greenhouse on the campus of New Mexico State University. The field area is typical of the arid phase of semidesert grassland, with an average annual precipitation (1915-1970) of $22.5 \mathrm{~cm}$. Of this total, 55\% occurs during the growing season, which is July, August, and September (Dwyer 1972). Most of the remaining precipitation occurs in the fall and winter. Summer rainfall usually comes from highintensity, convectional thunderstorms (Paulsen and Ares (1962). Annual rainfall is highly variable, and drought is common. The frost-free period is approximately 200 days, but the actual growing season varies between 90 and 100 days because of soil water limitations (Miller and Donart 1979).

Major species on the study area included mesa dropseed (Sporobolus flexuosus [Thurb.] Rydb.), spike dropseed (Sporobolus contractus Hitchc.), fluffgrass (Erioneuron pulchellum [H.B.K.] Tateoka), black grama (Bouteloua eriopoda [Torr.] Torr.), broom snakeweed, and honey mesquite (Prosopis juliflora [Sw.] DC.). More than 48 other plant species were identified.

Study sites were within the Wink soil series, as determined by the Soil Conservation Service (1974). The Wink soil series consists of a sandy loam surface layer, ranging from 12 to $150 \mathrm{~cm}$ in depth, overlaying a caliche layer. Thickness of the topsoil of the caliche horizon ranges from 42 to $67 \mathrm{~cm}$, and the soil is classified as a deep sandy loam. Permeability is moderately rapid and the soil is welldrained with little surface runoff.

\section{Materials and Methods}

In July 1980, 10 square-meter plots were located in a 20-year-old exclosure. Sample quadrats encompassed only 1 broom snakeweed plant located at the center of each quadrat. Each quadrat was divided into 3 distance zones: $0-20 \mathrm{~cm}\left(1,600 \mathrm{~cm}^{2}\right), 21-30 \mathrm{~cm}(2,000$ $\left.\mathrm{cm}^{2}\right)$, and $31-50 \mathrm{~cm}\left(6,400 \mathrm{~cm}^{2}\right)$ from the central broom snakeweed stem.

Four soil samples were collected from a $10.2-\mathrm{cm}$ core to a $5 \mathrm{~cm}$ depth from each zone and in 4 different directions (east, west, south, and north) from the central broom snakeweed plant. Snakeweed plants were mature and about $40-60 \mathrm{~cm}$ tall. Soil samples from the 4 cores collected by zone were thoroughly mixed and air-dried. In the greenhouse, soil samples were placed $2 \mathrm{~cm}$ deep over sterile sand in perforated pots $17.5 \mathrm{~cm}$ in diameter and 20 $\mathrm{cm}$ tall. Soil containers were watered as needed to maintain soil water near field capacity. Composite soil samples collected from each zone were replicated 3 times in a completely randomized design. Seedlings that emerged from each treatment were identified 

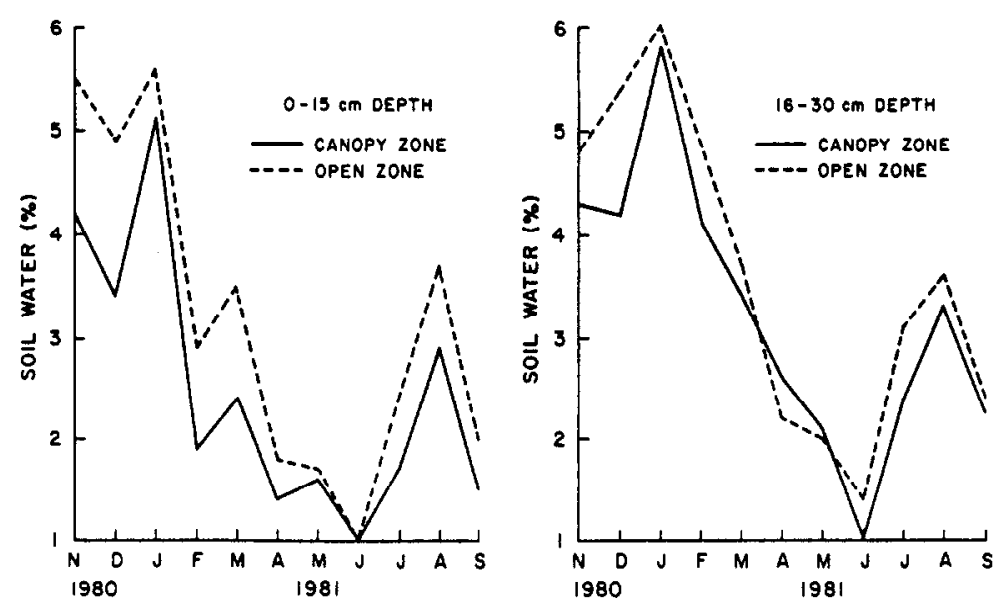

Fig. 1. Average soil water content in area beneath the snakeweed canopies and in open areas in 2 depths. Standard errors were as follows: 0 -15 cm, beneath canopy - 0.53, open - 0.48; 16-30 cm, beneath canopy - 0.56, open - 0.59.

and recorded daily. These were considered the number of viable seeds in the soil, although some seeds may germinate but not emerge. The seedlings were removed from the pots after they were identified. Records were kept for 10 months (August 1980 to May 1981). Density of seedlings was calculated on the basis of the original core size.

Vegetation on the field locations was sampled in September 1980 to determine plant density. Density of plants was determined separately for each zone (20-, 30-, and 50-cm distances) by counting all plants in each zone for all 10 quadrats in the exclosure.

Soil water was determined gravimetrically at 2 locations inside the canopy zone and outside the canopy zone of broom snakeweed. Soil water was determined at 2 depths $(0-15$ and $15-30 \mathrm{~cm})$. Data were analyzed by analysis of variance procedures (Steel and Torrie 1960), to compare emergence in soils collected at different distances from snakeweed plants. When the analysis of variance indicated a significant difference, means were compared by Tukey's procedure.

\section{Results and Discussion}

Densities of grasses and forbs emerging from the pots were significantly different $(P<0.05)$ among the 3 zones around the central broom snakeweed plant. Three different patterns of plant emergence from soils collected at varying distances from the central snakeweed plant were noted under greenhouse conditions. The first pattern was exemplified by the 2 dropseed species ( $S$. contractus and $S$. flexuosus), whose densities were higher in the zones closest and most distant from the central snakeweed plant (Table 1). Forbs such as spectaclepod (Dithyrea wislizenii Engelm.), tansy mustard (Descurainia pinnata [Walt.] Britton), and annual snakeweed (Gutierrezia wrightii Greene) exhibited a similar pattern.

Another pattern was a declining density in relation to distance from broom snakeweed plants. Species exhibiting this pattern were black grama, fluffgrass, red three awn (Aristida longiseta Steud.), portulaca (Portulaca mundula Johnst.), and globemallow (Sphaeralcea incana (Torr.). Other species such as locoweed (Astragalus tephrodes Gray) and deer tongue (Crypantha crassisepala Torr. \& Gray) were more abundant in the zone next to the broom snakeweed plant than in the other 2 zones (Table 1), and represented the third pattern.

Patterns in the field were not so clear-cut and densities were much lower than those in the greenhouse (Table 2). Many species showed an increase in density away from the central snakeweed plant. These species included red three awn, black grama, both species of dropseed, desert holly (Perezia nana Gray), and globemallow. Species showing higher densities close to the snakeweed
Table 1. Average numbers of seedlings $\left(\mathrm{no} / \mathrm{m}^{2}\right)$ emerging from soil collected from 20,30 and $50 \mathrm{~cm}$ distances from broom snakeweed plants under greenhouse conditions.

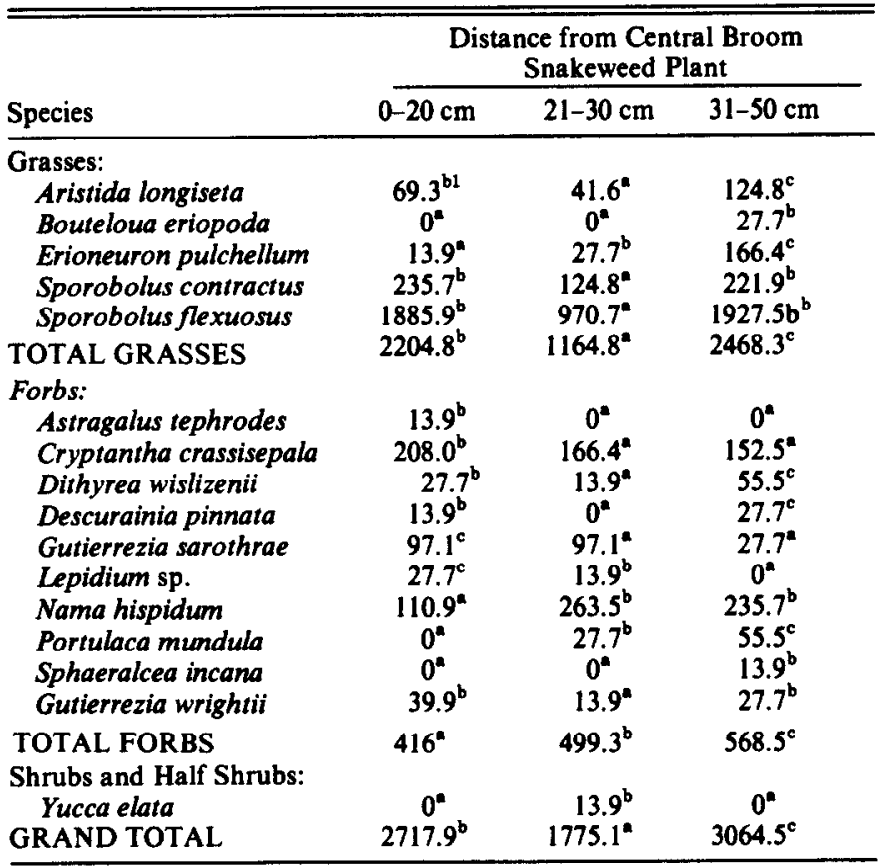

'Means with different letters are significantly different among distance zones $(P<0.05)$.

plant included fluffgrass, leatherweed croton (Croton corymbulosus Englem.), and broom snakeweed (Table 2).

The presence of viable seeds in the soil might be influenced by the distribution of parent plants, and by obstructions that impede blowing inflorescences and other propagules. Because many species were more abundant in the field in the zone $50 \mathrm{~cm}$ from the central snakeweed plant, emergence of seedlings from soil in the outer zone might be related to a greater density of parent plants in these zones. The distribution of seeds is also related to the motility of seeds.

Many grass inflorescences tend to brcak off when the plant matures. Broom snakeweed plants act as a barrier to the blowing inflorescences, and seeds of such species as mesa dropseed and three awn accumulate around the base of the broom snakeweed plants. 


\section{Literature Cited}

Table 2. Density of different plant specles at different distances from a broom anakeweed plant under field conditions.

\begin{tabular}{|c|c|c|c|}
\hline \multirow[b]{2}{*}{ Species } & \multicolumn{3}{|c|}{$\begin{array}{c}\text { Distance from Central Broom } \\
\text { Snakeweed Plant } \\
\end{array}$} \\
\hline & $0-20 \mathrm{~cm}$ & $21-30 \mathrm{~cm}$ & $31-50 \mathrm{~cm}$ \\
\hline & \multicolumn{3}{|c|}{$\left(\mathrm{No} / \mathrm{m}^{2}\right)$} \\
\hline $\begin{array}{l}\text { Grasses: } \\
\text { Aristida longiseta } \\
\text { Bouteloua eriopoda } \\
\text { Erioneuron pulchellum } \\
\text { Scleropogon brevifolius } \\
\text { Sporobolus contractus } \\
\text { Sporobolus flexuosus }\end{array}$ & $\begin{array}{l}0^{\mathrm{al}} \\
0.6^{\mathrm{a}} \\
1.9^{\mathrm{b}} \\
0.6^{\mathrm{a}} \\
0^{\mathrm{a}} \\
1.3^{\mathrm{a}}\end{array}$ & $\begin{array}{l}1.0^{\mathrm{b}} \\
2.0^{\mathrm{b}} \\
1.0^{\mathrm{a}} \\
1.5^{\mathrm{b}} \\
0^{\mathrm{a}} \\
1.5^{\mathrm{a}} \\
\end{array}$ & $\begin{array}{l}1.4^{\mathrm{b}} \\
2.8^{\mathrm{c}} \\
0.9^{\mathrm{a}} \\
0.8^{\mathrm{a}} \\
0.2^{\mathrm{a}} \\
4.2^{\mathrm{b}}\end{array}$ \\
\hline Total Grasses & $4.4^{\prime \prime}$ & $7.0^{b}$ & $\overline{10.3^{c}}$ \\
\hline $\begin{array}{l}\text { Forbs } \\
\text { Croton corymbulosus } \\
\text { Dithyrea wislizenii } \\
\text { Perezia nana } \\
\text { Salsola kali } \\
\text { Solanum elaegnifolium } \\
\text { Sphaeralcea incana } \\
\text { Tidestromia lanuginosa }\end{array}$ & $\begin{array}{l}1.9^{b} \\
0.6^{a} \\
0^{a} \\
0.6^{a b} \\
0^{a} \\
0^{a} \\
0^{a} \\
\end{array}$ & $\begin{array}{l}2.0^{\mathrm{b}} \\
0.5^{\mathrm{a}} \\
1.0^{\mathrm{b}} \\
0^{\mathrm{a}} \\
1.0^{\mathrm{b}} \\
0.5^{\mathrm{b}} \\
0^{\mathrm{a}} \\
\end{array}$ & $\begin{array}{l}1.2^{\mathrm{a}} \\
0^{\mathrm{a}} \\
0.8^{\mathrm{b}} \\
1.4^{\mathrm{b}} \\
0.3^{\mathrm{ab}} \\
0.9^{\mathrm{b}} \\
0.2^{\mathrm{a}}\end{array}$ \\
\hline Total Forbs & $\overline{3.1^{\mathrm{a}}}$ & $5.0^{b}$ & $4.8^{b}$ \\
\hline $\begin{array}{l}\text { H̀alf Shrub } \\
\quad \text { Gutierrezia sarothrae }\end{array}$ & $6.2^{b}$ & $0^{n}$ & $0^{*}$ \\
\hline
\end{tabular}

${ }_{1}^{1}$ Means with different letters are significantly different amount distance zones $(P<0.05)$.

Under field conditions, broom snakeweed plants may modify the microenvironment by adding allelopathic substances to the soil (McDaniel et al. 1984), by shading, by removing soil water, and by intercepting precipitation. Soil water, especially in the upper 15 $\mathrm{cm}$, was usually lower $(P<0.05)$ under snakeweed canopies than in the open spaces around the snakeweed plants (Fig. 1). These phenomena may explain the lack of plants in the zone next to the snakeweed plants. Other studies have shown considerable increases in herbaceous production following removal of dense broom snakeweed stands (McDaniel et al. 1982, Ueckert 1979).
Campbell, R.S., and D.H. Bomberger. 1934. The occurrence of Gutierrezia sarothrae on Bouteloua eriopoda range in southern New Mexico. Ecol. 15:49-51.

Dwyer, D.D. 1972. Burning and nitrogen fertilization of tobosa grass. New Mex. Agr. Exp. Sta. Bull. 595.

Jameson, A.D. 1970. Value of broom snakeweed as a range condition indication. J. Range Manage. 23:302-304.

Jenny, H. 1961. Derivation of state factor equations of soils and ecosystem. Soil Sci. Soc. Amer. Proc. 25:385-388.

Juhren, M., F.W. Went, and E. Phillips. 1956. Ecology of desert plants. IV. Combined field and laboratory work on germination of annuals in the Joshua Tree National Monument, California. Ecol. 37:318-330.

Major, J. 1951. A functional factorial approach to plant ecology. Ecol. 32:392-412.

Major, J. and W.T. Pyott. 1966. Buried viable seed in two California bunchgrass sites and their bearing on the definition of a flora. Vegetatio 13:253-282.

McDaniel, K.C., R.D. Pieper, and G.B. Donart. 1982. Grass response following thinning of broom snakeweed. J. Range Manage. 35:219-222.

McDaniel, K.C., R.D. Pieper, L.E. Loomis, and A.A. Osman. 1984. Taxonomy and ecology of perennial snakeweeds in New Mexico. New Mex. Agr. Exp. Sta. Bull. 711.

Miller, R.F., and G.B. Donart. 1979. Response of Boutelowa eriopoda (Torr.) Torr. and Sporobolus flexuosus (Thurb.) Rydb. to season of defoliation. J. Range Manage. 32:63-66.

Mott, J.J. 1972. Germination studies on some annual species from an arid region of western Australia. J. Ecol. 60:293-304.

Nava, G. 1970. Occurrence of vegetation and emergence of species from surface soil collected on two southwestern desert range sites. M.S. Thesis. New Mex. State Univ., Las Cruces.

Paulsen, H.H., and F.N. Ares. 1962. Grazing value and management of black grama and tobasa grassland and associated shrub ranges of the Southwest. USDA Tech. Bull. 1270.

Soll Conservation Service. 1974. Soil survey of Dona Ana County area, New Mexico.

Steel, R.G.D., and J.H. Torrie. 1960. Principles and procedures of statistics. McGraw-Hill Book Co., Inc., New York.

Ueckert, D.N. 1979. Broom snakeweed: Effect on shortgrass forage production and soil water depletion. J. Range Manage. 32:216-219.

Vallentine, J.R. 1971. Range development and improvement. Brigham Young University Press, Provo.

\section{Do you read? \\ write for? \\ or review for}

the Joumal of Range Mantogement or Rangelands? If the answer is "yes" to any of the above questions, put down the symposium You and SRM Publications for a DO NOT MISS at the SRM Annual Meeting in Corpus Christi, Texas, in February. 